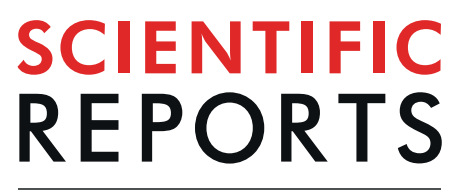

natureresearch

Check for updates

\title{
OPEN Impact of warming and reduced precipitation on morphology and chlorophyll concentration in peat mosses (Sphagnum angustifolium and S. fallax)
}

\author{
Anshu Rastogi ${ }^{1,6 \bowtie}$, Michal Antala ${ }^{1,4,6}$, Maciej Gąbka ${ }^{2 凶}$, Stanisław Rosadziński ${ }^{3}$, \\ Marcin Stróżecki ${ }^{1}{ }^{1}$, Marian Brestic $\mathbb{B}^{4,5}$ \& Radosław Juszczak ${ }^{1}$
}

Peatlands are one of the most important ecosystems due to their biodiversity and abundant organic compounds; therefore, it is important to observe how different plant species in peatlands react to changing environmental conditions. Sphagnum spp. are the main component of peatlands and are considered as the creator of conditions favorable for carbon storage in the form of peat. Sphagnum angustifolium and Sphagnum fallax are taxonomically very close species. To examine their adaptability to climate change, we studied the morphology and pigment content of these two species from environmental manipulation sites in Poland, where the environment was continuously manipulated for temperature and precipitation. The warming of peat was induced by using infrared heaters, whereas total precipitation was reduced by a curtain that cuts the nighttime precipitation. Morphology of $S$. angustifolium stayed under climate manipulation relatively stable. However, the main morphological parameters of $S$. fallax were significantly affected by precipitation reduction. Thus, this study indicates S. angustifolium is better adapted in comparison to $S$. fallax for drier and warmer conditions.

Climate change is appearing to be the biggest problem of this century. It is estimated that anthropogenic activities have caused global warming by approximately $1.0^{\circ} \mathrm{C}$ in comparison with the pre-industrial era. The global warming rate is currently estimated to be $0.2^{\circ} \mathrm{C}$ per decade; therefore, it is a high probability that the average global temperature may reach $1.5^{\circ} \mathrm{C}$ higher in between 2032 and $2050^{1}$. Rainfall patterns affect surface wetness and water availability to plants; therefore, its alteration may directly impact the primary productivity ${ }^{2}$. In this changing environmental condition, plants may either adapt, move to suitable climatic conditions, or may get extinct ${ }^{3}$. With the change in plant species composition, the ecosystem may also lose its identity and can turn into a different ecosystem with changing environmental conditions $s^{4}$. Therefore, to understand the faith of the ecosystem in changing environmental conditions, it is crucial to study the behavior of different plant species.

Due to their high carbon storage capacity, peatlands are considered to be one of the most important ecosystems ${ }^{5}$. Peatlands cover only around 4 million $\mathrm{km}^{2}$ what amounts to $3 \%$ of the world's terrestrial area, but contains around one-third of the terrestrial carbon ${ }^{6}$. About $80 \%$ of the world's peatlands occur in the northern hemisphere ${ }^{7}$, and they constitute about $515000 \mathrm{~km}^{2}$ in Europe ${ }^{6}$. Due to their high carbon storage, peatlands have attracted a lot of attention to environmental scientists ${ }^{8-10}$. It is still uncertain that under new climatic conditions (due to warming and changed precipitation) pristine peatlands will work like carbon sink or they will become a

${ }^{1}$ Laboratory of Bioclimatology, Department of Ecology and Environmental Protection, Poznan University of Life Sciences, Piątkowska 94, 60-649, Poznan, Poland. ${ }^{2}$ Department of Hydrobiology, Adam Mickiewicz University in Poznań, Uniwersytetu Poznańskiego 6, 61-614, Poznań, Poland. ${ }^{3}$ Adam Mickiewicz University in Poznań, Uniwersytetu Poznańskiego 6, 61-614, Poznań, Poland. ${ }^{4}$ Department of Plant Physiology, Slovak University of Agriculture, A. Hlinku 2, 94976, Nitra, Slovak Republic. ${ }^{5}$ Department of Botany and Plant Physiology, Faculty of Agrobiology, Food and Natural Resources Czech University of Life Sciences, 16500 Prague, Czech Republic. ${ }^{6}$ These authors contributed equally: Anshu Rastogi and Michal Antala. ${ }^{凶}$ e-mail: anshu.rastogi@up.poznan.pl; gmaciej@ amu.edu.pl 
source of carbon ${ }^{8,9}$. The peatland vegetation is considered to be diverse with very complex and nonlinear behavior. Recently it has been shown that each species in peatlands may behave differently to changed environmental conditions, where the new ecological condition in peatlands may suit one species for its better growth, whereas other plant species may get impacted adversely ${ }^{10}$.

Sphagnum spp. are the most important components of the northern peatlands ${ }^{11}$. They are the key regulators of peatlands ecosystems as they create acidic, nutrient-poor, cold, and anoxic conditions, in which just a few other species can grow ${ }^{12,13}$. The photosynthesis in Sphagnum occurs only in the top $10 \mathrm{~mm}$ of the plant, mostly in the capitulum, but the lower part remains still alive and holds the ability to create side shoot in case of a damaging ape ${ }^{14}$. Sphagnum, like all bryophytes, does not have roots and conducting tissues ${ }^{15}$. It can absorb water and nutrients through the plant's surface ${ }^{12}$. Very efficient water conduction and retention are possible due to the arrangement of stems, branches, and leaves of Sphagnum. Moreover, capillary conductance is supported by large hyaline cells with pores, which occupy a substantial part of tissues, larger than alive chlorophyll-containing cells and by growth in closely packed clusters ${ }^{16,17}$. The Sphagnum spp., unlike vascular plants, are poikilohydric (lack cuticle and stomata) and belong to poikilochlorophyllous plants (desiccation results in the loss of chlorophyll); therefore, photosynthesis is dependent on water uptake by capillary action, precipitation, and stored water in the plant $^{18,19}$. Thus, the Sphagnum spp. are considered to be sensitive to increasing temperature and drought stress ${ }^{20,21}$. Understanding how these mosses response to climate change is one of the challenges towards understanding biodiversity on peatlands. Recently it was shown that phenotypic plasticity occurs among dominant Sphagnum spp., which allows the plant community to cope up with the changing environmental condition ${ }^{21}$.

Two of the most common species for poor fen peatlands are Sphagnum angustifolium (fine bogmoss) and Sphagnum fallax (flat-topped bogmoss) which may quite often occur together ${ }^{22}$. The plants belong to section Cuspidata, the section with hollow species, which has developed a "drought avoidance" strategy to avoid desiccation through its effective water holding morphology $\mathrm{y}^{23-25}$. Because of its similarity and importance as peatlands restoration species, S. angustifolium and S. fallax were selected for this study ${ }^{26,27}$, where both species were compared for morphological changes and their pigment content under different environmental manipulated conditions.

The plant samples were collected from Rzecin peatland in Poland, where a unique climate manipulation site occurs $^{10}$. The microclimate there is manipulated since 2014. The plants were collected from the plots which were continuously manipulated for 4 years by effective methods to create conditions similar to the expected change in climatic conditions in the next decades. The aim of our study was to answer the following questions: (1) does warming and reduced precipitation affected the morphology and pigment concentration of Sphagnum species? (2) does one species of Sphagnum sustained better in changed environment conditions when compared with the other?

Through this study, we also tried to prove the hypothesis that with climate change one Sphagnum species will be replaced with other suitable Sphagnum species.

\section{Results}

Variability in micrometeorological data of manipulated plots. The experiment was conducted in Rzecin $\left(52^{\circ} 45^{\prime} 43^{\prime \prime} \mathrm{N} 16^{\circ} 18^{\prime} 35^{\prime} \mathrm{E}, 54 \mathrm{~m}\right.$ a.s.l.) peatland area in Poland. The microclimate of the site was continuously manipulated from 2014 to $2018^{10,28-31}$. Temperature and precipitation were recorded continuously at each of the four experimental sites marked as Control (C), Warming (W), Warming and Reduced Precipitation (WRP) and Reduced Precipitation (RP).

We observed a substantial variability of precipitation between the years. The year of 2017 was observed with the highest precipitation (Fig. 1A) sum of $929 \mathrm{~mm}$, whereas 2015 was the driest among the studied years with a yearly sum of $417 \mathrm{~mm}^{29}$. The reduction in precipitation due to manipulation (in RP and WRP sites) was ca. 37\% in years $2015-2016^{29-31}$, while in 2017 and 2018 it was smaller $-24 \%$ and $10 \%$ respectively, in comparison to the sites without a reduction in precipitation (C and W). Low precipitation reduction in the years 2017 and 2018 was caused due to the failure of the automated curtain system by a very strong storm in July 2017.

The average mean temperature of the peat was measured from $50 \mathrm{~mm}$ depth. The average annual peat temperature from all manipulated plots was observed to be higher on average by ca. $1.0^{\circ} \mathrm{C}$ in the dry years $2015-2016^{29-31}$ and $0.9^{\circ} \mathrm{C}$ in very wet 2017 , in comparison to $\mathrm{C}$ plots. The year of 2018 was exceptional, where the increase in peat temperature was only around $0.2^{\circ} \mathrm{C}$ for $\mathrm{W}$ plots, whereas for $\mathrm{RP}$ plots the increase was around $0.6^{\circ} \mathrm{C}$ in comparison to $\mathrm{C}$ plots (Fig. 1A). The increase in average peat temperature was the highest for WRP sites and ranged from 0.7 to $0.8^{\circ} \mathrm{C}$ comparing to $\mathrm{C}$ in $2017-2018$.

As vegetation period or summer plays an important role in the plant life cycle, we have drawn the graph presenting changes in temperature and precipitation during vegetation period (April till October; Fig. 1B) and summer (June till August; Fig. 1C). Precipitation during vegetation period was observed to be reduced by $30 \%$ and $12 \%$ in 2017 and 2018, respectively, whereas, the summer precipitation was observed to be reduced by $36 \%$ and $10 \%$ for the years 2017 and 2018, respectively. During the studied period the difference in average peat temperature, in relation to $\mathrm{C}$, for $\mathrm{W}$ site was observed to be between $0.2-0.6^{\circ} \mathrm{C}$ during the vegetation period, whereas it was $0.2-0.3^{\circ} \mathrm{C}$ for summer. The differences in average mean peat temperature for RP sites was $0.4-0.7^{\circ} \mathrm{C}$ and $0.3-0.6^{\circ} \mathrm{C}$ for WRP sites and $0.8-1.4^{\circ} \mathrm{C}$ and $0.3-1.1^{\circ} \mathrm{C}$ for the vegetation period and summer, respectively.

Impact of warming and reduced precipitation on the morphology of Sphagnum. Sixteen different morphological traits related to plant length, capitulum, and branch length were measured. As the peatlands show dynamic and nonlinear behavior, the obtained data were analyzed in two ways, where the plant species from plots were separately analyzed by general linear mixed-effect models (GLMM) and ANOVA to observe the differences (Supplement Tables S1-3). Data were analyzed for significant differences between sites (C, W, WRP and RP) 
A

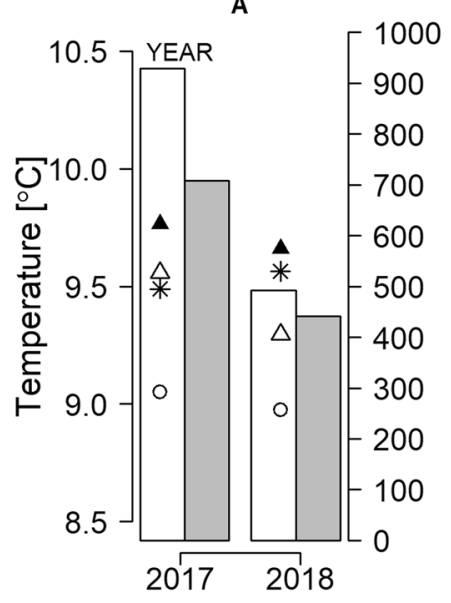

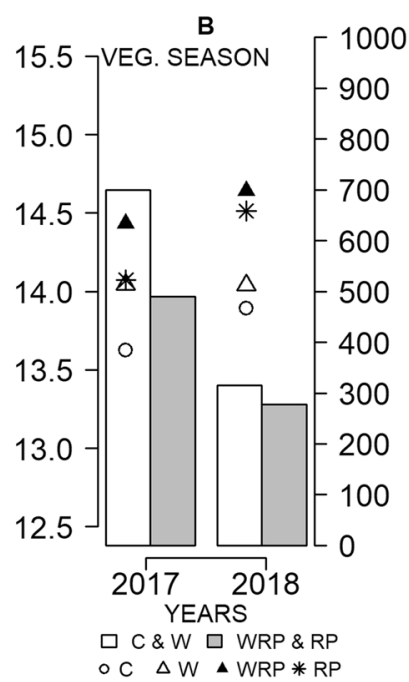

C

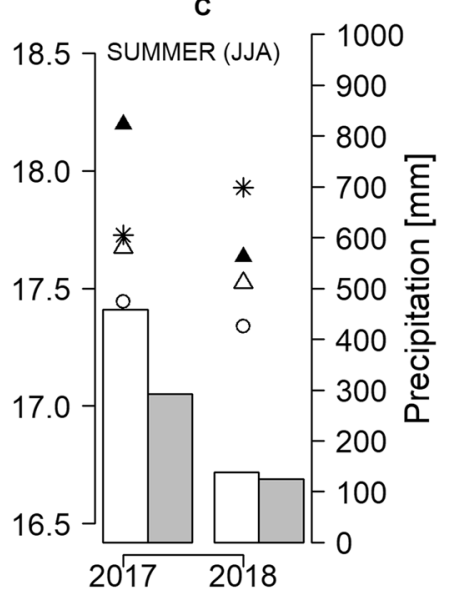

Figure 1. Mean temperature of peat measured at $50 \mathrm{~mm}$ depth and the amount of precipitation at control (C), warming (W), warming and reduced precipitation (WRP), and reduced precipitation (RP) sites of WETMAN climate manipulation experiment at Rzecin peatland for whole year (A), vegetation season from April till October (B) and summer from June till August (C). Warming was induced by the use of infrared heaters while precipitation was reduced by the curtain, which cut the amount of nighttime precipitation. Due to system failure, there was minimal precipitation reduction in 2018.

for every trait and every species separately (Tables 1-2). No significant changes between sites were observed in the length of whole plant and its green part for S. angustifolium, whereas the length of the brown part was significantly lower in W (Table 1). Dry mass of plant as well capitulum dry mass and its diameter in manipulated sites were not significantly different from $\mathrm{C}$ (Table 1 ).

In the case of $S$. fallax, very important morphological traits like length of whole plant, its green or brown part, diameter and dry mass of capitulum showed significant differences between sites (Table 2). The highest values of parameters total length, length of brown part and capitulum diameter were observed in the $\mathrm{C}$. The lowest values of length of plant and its parts, capitulum diameter and its dry mass were recorded in sites with manipulated precipitation (Table 2).

Impact of warming and reduced precipitation on pigments of Sphagnum. The concentration of chlorophyll-a (chl a), chlorophyll-b (chl b), and carotenoids were observed from both the plant species from different experimental sites. In S. angustifolium all the observed pigments were higher in comparison to $S$. fallax. A decrease in all the studied pigments was observed for the RP sites for both the studied species in comparison to C. Carotenoid content was higher for W and WRP for S. fallax, whereas it was observed to be relatively stable for S. angustifolium. The ratio of chl a and chl b was observed to be slightly higher for both the studied plants in W and WRP sites in comparison to $\mathrm{C}$.

\section{Discussion and Conclusions}

Dominating plant species plays an important role in ecosystem sustainability. With the change in environment, the conditions in the ecosystem may change which may favor one species more than others. The new favorable species may accelerate the process of change in microhabitat, which may cause the transformation of the ecosystem. Therefore, the study related to species response to changing environmental conditions is important. In this study, we have shown how the two very similar and important plant species of peatlands reacted to the environmental change through climate manipulation experiments. S. angustifolium and $S$. fallax are very similar species from section Cuspidata. They are commonly found to coexist together, like in the Rzecin peatland area in Poland. Sphagnum spp. are considered to be sensitive towards water availability, change in water conductivity, and $\mathrm{pH}$ due to precipitation or temperature change ${ }^{20,32}$. S. fallax can grow under more acidic condition (i.e. from 3.1 to $6.1 \mathrm{pH})$ in comparsion to $S$. angustifolium $(3.8$ to $7 \mathrm{pH})$. Therefore, alteration in precipitation or temperature can alter the Sphagnum community in peatlands. A recent study has shown that the Sphagnum community declined under warmer conditions but has considered S. angustifolium and S. fallax together assuming that they have similar responses to change in environmental conditions ${ }^{20}$, whereas in this study, we have observed that $S$. angustifolium and S. fallax reacted differently to warming and reduced precipitation. The different responses of plant species were analyzed through the observation of plant morphology and pigment composition after four years of continuous exposure of plants to manipulated conditions, and their comparison to the observations from the plants without manipulations.

Several authors ${ }^{23,33,34}$ reported a significant increase in plant length of Sphagnum spp. under warmer conditions when compared with control, whereas, we observed a slight decrease in total plant length for both the plant species for W. Interestingly plants from WRP and RP showed the opposite response to manipulation for both the studied plants, where S. angustifolium was observed to be slightly longer and S. fallax was observed to 


\begin{tabular}{|c|c|c|c|c|c|c|c|c|}
\hline \multirow[b]{2}{*}{ Trait [unit] } & \multicolumn{2}{|l|}{$\mathrm{C}$} & \multicolumn{2}{|l|}{ W } & \multicolumn{2}{|l|}{ WRP } & \multicolumn{2}{|l|}{ RP } \\
\hline & Mean & Min.-Max. & Mean & Min.-Max. & Mean & Min.-Max. & Mean & Min.-Max. \\
\hline length of whole plant [mm] & $88^{\mathrm{a}}$ & $57-144$ & $72^{\mathrm{a}}$ & $53-94$ & $93^{\mathrm{a}}$ & $63-174$ & $89^{\mathrm{a}}$ & 49-199 \\
\hline length of green part [mm] & $33^{\mathrm{a}}$ & $20-51$ & $41^{\mathrm{a}}$ & $22-55$ & $40^{\mathrm{a}}$ & $19-64$ & $36^{\mathrm{a}}$ & $8-56$ \\
\hline length of brown part [mm] & $55^{\mathrm{ac}}$ & $17-105$ & $31^{\mathrm{b}}$ & $9-54$ & $54^{\mathrm{ac}}$ & $0-116$ & $52^{\mathrm{abc}}$ & $12-143$ \\
\hline length of green/brown part & $0.81^{\mathrm{ac}}$ & $0.19-2.55$ & $1.84^{\mathrm{b}}$ & 0.45 .6 .11 & $0.83^{\mathrm{ac}}$ & $0.24-1.61$ & $1.04^{\mathrm{abc}}$ & $0.20-3.92$ \\
\hline diameter of capitulum [mm] & $12.7^{\mathrm{a}}$ & $6.2-21-2$ & $10^{\mathrm{a}}$ & $5.6-17.8$ & $12.5^{\mathrm{a}}$ & $7.3-18.8$ & $12.5^{\mathrm{a}}$ & $7.9-19.5$ \\
\hline dry mass of whole plant [g] & $0.019^{\mathrm{a}}$ & $0.007-0.031$ & $0.027^{\mathrm{a}}$ & $0.007-0.054$ & $0.026^{\mathrm{a}}$ & $0.006-0.053$ & $0.022^{\mathrm{a}}$ & $0.006-0.045$ \\
\hline dry mass of capitulum [g] & $0.008^{\mathrm{ab}}$ & $0.003-0.014$ & $0.011^{\mathrm{ab}}$ & $0.002-0.024$ & $0.012^{\mathrm{ab}}$ & $0.004-0.023$ & $0.006^{\mathrm{a}}$ & $0.001-0.016$ \\
\hline length of 1-st spreading branch [mm] & $8.9^{\mathrm{ab}}$ & $4.1-11.6$ & $8.9^{\mathrm{ab}}$ & $5.2-17.7$ & $11.6^{\mathrm{c}}$ & $7.5-16.9$ & $10.4^{\mathrm{abc}}$ & $4.7-15.6$ \\
\hline length of 2-nd spreading branch [mm] & $9.3^{\mathrm{ab}}$ & $5.5-11.9$ & $8.7^{\mathrm{ab}}$ & $5.5-13.6$ & $12.1^{\mathrm{c}}$ & $7.2-17.3$ & $10.8^{\mathrm{abc}}$ & $7.2-15.1$ \\
\hline length of 3-rd spreading branch [mm] & $9.5^{\mathrm{a}}$ & $7.2-13.3$ & $9.4^{\mathrm{a}}$ & $5.4-16.7$ & $11.3^{\mathrm{a}}$ & $6.7-16.2$ & $10.6^{\mathrm{a}}$ & $6.6-13.7$ \\
\hline length of 1-st hanging branch [mm] & $12.6^{\mathrm{a}}$ & $6.7-18.4$ & $11.6^{\mathrm{a}}$ & $5.9-16.7$ & $14.7^{\mathrm{a}}$ & $8.8-22.5$ & $12.9^{\mathrm{a}}$ & $4.3-13.7$ \\
\hline length of 2-nd hanging branch [mm] & $12.3^{\mathrm{ab}}$ & $8.1-16.9$ & $13.1^{\mathrm{abc}}$ & $6.7-19.7$ & $15.6^{\mathrm{bc}}$ & $9.2-23.4$ & $13.1^{\mathrm{abc}}$ & $8.5-16.5$ \\
\hline length of 3-rd hanging branch [mm] & $11.7^{\mathrm{ab}}$ & $6.7-15.5$ & $12.9^{\mathrm{abc}}$ & $7.2-18.0$ & $14.8^{\mathrm{bc}}$ & $9.6-21.9$ & $13.5^{\mathrm{abc}}$ & $9.2-17.0$ \\
\hline length of 1-st internodium [mm] & $2.6^{\mathrm{a}}$ & $1.2-4.9$ & $2.8^{\mathrm{a}}$ & $1.2-6.6$ & $2.1^{\mathrm{a}}$ & $0.6-3.4$ & $2^{\mathrm{a}}$ & $0.5-4.4$ \\
\hline length of 2-nd internodium [mm] & $2.7^{\mathrm{a}}$ & $0.9-6.1$ & $3.2^{\mathrm{a}}$ & $0.6-6.1$ & $2.2^{\mathrm{a}}$ & $0.4-4.3$ & $2.2^{\mathrm{a}}$ & $1.0-5.6$ \\
\hline length of 3-rd internodium [mm] & $3.2^{\mathrm{a}}$ & $1.5-8.1$ & $3.9^{\mathrm{a}}$ & $1.4-7.8$ & $2.7^{\mathrm{a}}$ & $0.9-7.9$ & $2.2^{\mathrm{a}}$ & $0.7-4.2$ \\
\hline total chlorophyll content $\left[\mathrm{mg} . \mathrm{l}^{-1}\right]$ & $12.3^{\mathrm{a}}$ & $6.0-23.9$ & $9.9^{\mathrm{a}}$ & $4.6-15.6$ & $12.5^{\mathrm{a}}$ & $5.5-18.7$ & $10.0^{\mathrm{a}}$ & $4.9-15.6$ \\
\hline chlorophyll a [mg.l $\left.\mathrm{l}^{-1}\right]$ & $7.8^{\mathrm{a}}$ & $3.8-14.8$ & $6.3^{\mathrm{a}}$ & $3.0-10.1$ & $8.0^{\mathrm{a}}$ & $3.6-12.4$ & $4.9^{\mathrm{a}}$ & $3.1-6.3$ \\
\hline chlorophyll b [mg.l $\mathrm{l}^{-1}$ ] & $4.5^{\mathrm{a}}$ & $2.2-9.1$ & $3.5^{\mathrm{a}}$ & $1.6-5.5$ & $4.4^{\mathrm{a}}$ & $1.9-6.7$ & $3.6^{\mathrm{a}}$ & $1.8-5.5$ \\
\hline $\mathrm{chl} \mathrm{a/chl} \mathrm{b}$ & $1.7^{\mathrm{a}}$ & $1.3-2.0$ & $1.8^{\mathrm{a}}$ & $1.6-1.8$ & $1.8^{\mathrm{a}}$ & $1.6-2.0$ & $1.5^{\mathrm{a}}$ & $0.7-1.91 .6$ \\
\hline carotenoids [mg.l-1 $\left.{ }^{-1}\right]$ & $2.6^{\mathrm{a}}$ & $1.3-4.9$ & $2.4^{\mathrm{a}}$ & $1.2-3.7$ & $2.7^{\mathrm{a}}$ & $1.7-3.2$ & $2.1^{\mathrm{a}}$ & $1.0-3.5$ \\
\hline
\end{tabular}

Table 1. Average, minimal and maximal values of Sphagnum angustifolium traits in control (C), warming (W), warming and reduced precipitation (WRP) and reduced precipitation (RP) conditions. Mean values with different letters $(\mathrm{a}-\mathrm{c})$ within each of the traits are significantly different from each other $(\mathrm{p}<0.05)$.

be significantly shorter in comparison to C. Length of green and brown part almost followed the similar pattern except for W, where the length of green part was observed to be slightly longer in comparison to control. The longer green part in $\mathrm{W}$ can be the influence of better light penetration which may be higher in W because of the compactness of capitulum, which can be seen by lower diameter and higher dry mass capitulum in W. The observation clearly indicated that the growth of studied species was strongly correlated with precipitation in comparison to temperature, which was in agreement with the previous study ${ }^{35}$. Further studies should corroborate if this is a common feature throughout the different ecoregions.

Most of the light absorption and $\mathrm{CO}_{2}$ assimilation occurs in the topmost part of Sphagnum plants, which is known as capitulum ${ }^{36}$. The warming of the environment may induce the growth of Sphagnum and stimulate dry matter production as long as the water availability is sufficient ${ }^{36}$. But higher temperatures may lead to higher evapotranspiration, which makes the peat dry. Therefore, the capitulum of Sphagnum gets smaller, a similar response was observed in our study. The water loss by evapotranspiration must be compensated by rain or capillary uptake from deeper peat layers ${ }^{37}$. The water loss from peatlands due to evapotranspiration cannot be restored by rainwater in $100 \%{ }^{36}$. The increased temperature was previously observed to increases capillary water flow and evapotranspiration ratio ${ }^{38}$. Sphagnum in dry conditions enters a state of desiccation, which significantly reduces evapotranspiration and photosynthesis ${ }^{39}$. If the plant capitulum is dry for a long time, less photosynthesis occurs which results in the reduction of plant growth. Therefore, the water content of capitulum is decisive for the growth of Sphagnum ${ }^{35,36,40}$. Shorter S. fallax plants with smaller capitulum in RP and WRP conditions in comparison with $C$ shows a negative influence of reduction in precipitation which indicates that the capillary uptake of water in $S$. fallax may probably not replace the loss of water due to evapotranspiration which results in poor growth of the plant. The capitula layer of Sphagnum controls evaporation and water retention in the plant ${ }^{39}$. Although the capitulum diameter differs between experimental sites, the differences were significant $(\mathrm{p}<0.05)$ just for $S$. fallax. As the reduced precipitation sites showed lower capitulum diameter for $S$. fallax, we can conclude that the capitulum diameter of $S$. fallax was depended on the precipitation.

The decrease in total dry mass of plant and dry mass of capitulum in W and WRP for S. fallax indicate the importance of water in dry mass production of mosses reported earlier ${ }^{41}$. The observation indicated $S$. fallax to be strongly influenced by reduced precipitation in comparison to S. angustifolium.

The shortest brown part (i.e. decaying part) was observed in WRP for S. fallax, whereas it was in W for $S$. angustifolium. The observation indicated that the best conditions for the decomposition of $S$. fallax peat were in WRP probably caused by better conditions for decomposing bacteria and saprotrophic fungi ${ }^{42,43}$. The observation is in agreement with the previous study where warmer and drier conditions have been reported to cause a $50 \%$ decrease in $S$. fallax occurrence and substantial reduction of productivity and photosynthetic activity with a significant increase in peat decomposition ${ }^{44}$.

S. fallax in C was observed to have a slightly bigger capitulum and longer plant then S. angustifolium. The observation indicates that the normal environmental condition was suitable for the coexistence of both the species, where both species may have long and healthy plants. Similar behavior of both species was observed from 


\begin{tabular}{|c|c|c|c|c|c|c|c|c|}
\hline \multirow[b]{2}{*}{ Trait [unit] } & \multicolumn{2}{|l|}{$\mathrm{C}$} & \multicolumn{2}{|l|}{ W } & \multicolumn{2}{|l|}{ WRP } & \multicolumn{2}{|l|}{ RP } \\
\hline & Mean & Min.-Max. & Mean & Min.-Max. & Mean & Min.-Max. & Mean & Min.-Max. \\
\hline length of whole plant [mm] & $81^{\mathrm{a}}$ & $47-140$ & $74^{\mathrm{ab}}$ & $49-124$ & $44^{\mathrm{c}}$ & $24-81$ & $54^{\mathrm{bc}}$ & $31-99$ \\
\hline length of green part [mm] & $44^{\mathrm{abc}}$ & $17-89$ & $50^{\mathrm{ab}}$ & $16-72$ & $33^{\text {ac }}$ & $24-45$ & $30^{\text {ac }}$ & $14-53$ \\
\hline length of brown part [mm] & $37^{\mathrm{ab}}$ & $13-75$ & $24^{\mathrm{abc}}$ & $0-63$ & $10^{\mathrm{bc}}$ & $0-45$ & $24^{\mathrm{abc}}$ & $0-56$ \\
\hline length of green/brown part & $1.60^{\mathrm{a}}$ & $0.36-5.80$ & $2.33^{\mathrm{a}}$ & $0.31-5.89$ & $2.49^{\mathrm{a}}$ & $0.80-6.40$ & $2.10^{\mathrm{a}}$ & $0.44-5.80$ \\
\hline diameter of capitulum [mm] & $13.0^{\mathrm{a}}$ & $6.6-20.1$ & $9.1^{\mathrm{b}}$ & $6.8-13.6$ & $6.8^{\mathrm{b}}$ & $4.9-8.9$ & $8.0^{\mathrm{b}}$ & $3.8-16.6$ \\
\hline dry mass of whole plant [g] & $0.024^{\mathrm{a}}$ & $0.005-0.074$ & $0.026^{\mathrm{a}}$ & $0.013-0.040$ & $0.009^{\mathrm{a}}$ & $0.003-0.014$ & $0.009^{\mathrm{a}}$ & $0.005-0.015$ \\
\hline dry mass of capitulum [g] & $0.007^{\mathrm{ac}}$ & $0.002-0.017$ & $0.011^{\mathrm{bc}}$ & $0.005-0.021$ & $0.005^{\mathrm{abc}}$ & $0.002-0.008$ & $0.003^{\text {ac }}$ & $0.002-0.005$ \\
\hline length of 1-st spreading branch [mm] & $10.3^{\mathrm{a}}$ & $4.4-15.5$ & $10.3^{\mathrm{a}}$ & $5.8-14.4$ & $11.3^{\mathrm{a}}$ & $6.4-18.7$ & $9.0^{\mathrm{a}}$ & $7.6-12.3$ \\
\hline length of 2-nd spreading branch [mm] & $10.6^{\mathrm{a}}$ & $4.6-17.9$ & $9.7^{\mathrm{a}}$ & $5.9-14.7$ & $10.6^{\mathrm{a}}$ & $7.8-15.9$ & $9.7^{\mathrm{a}}$ & $6.4-13.7$ \\
\hline length of 3-rd spreading branch [mm] & $10.7^{\mathrm{a}}$ & $5.1-19.0$ & $11.1^{\mathrm{a}}$ & $7.0-17.4$ & $10.6^{\mathrm{a}}$ & $5.5-15.3$ & $10.5^{\mathrm{a}}$ & $6.7-14.2$ \\
\hline length of 1-st hanging branch [mm] & $12.8^{\mathrm{a}}$ & $6.4-19.3$ & $12.4^{\mathrm{a}}$ & $8.3-16.9$ & $12.5^{\mathrm{a}}$ & $5.7-16.9$ & $10.5^{\mathrm{a}}$ & $7.0-13.8$ \\
\hline length of 2-nd hanging branch [mm] & $12.5^{\mathrm{a}}$ & $7.8-20.0$ & $12.5^{\mathrm{a}}$ & $6.7-15.8$ & $10.5^{\mathrm{a}}$ & $5.4-13.6$ & $10.5^{\mathrm{a}}$ & $7.0-12.2$ \\
\hline length of 3-rd hanging branch [mm] & $13.6^{\mathrm{a}}$ & $6.5-19.7$ & $12.9^{\mathrm{a}}$ & $7.2-18.5$ & $12.4^{\mathrm{a}}$ & $6.8-17.7$ & $10.5^{\mathrm{a}}$ & $6.1-14.6$ \\
\hline length of 1-st internodium [mm] & $2.8^{\mathrm{a}}$ & $1.0-3.9$ & $2.9^{\mathrm{a}}$ & $0.7-7.2$ & $1.8^{\mathrm{a}}$ & $0.7-3.2$ & $2.1^{\mathrm{a}}$ & $1.0-3.4$ \\
\hline length of 2-nd internodium [mm] & $3.4^{\mathrm{a}}$ & $1.3-6.8$ & $2.9^{\mathrm{a}}$ & $0.4-6.8$ & $2.2^{\mathrm{a}}$ & $1.1-4.2$ & $2.6^{\mathrm{a}}$ & $1.1-6.6$ \\
\hline length of 3-rd internodium [mm] & $3.7^{\mathrm{a}}$ & $1.4-5.6$ & $3.1^{\mathrm{a}}$ & $1.6-5.2$ & $3.1^{\mathrm{a}}$ & $1.5-7.4$ & $2.9^{\mathrm{a}}$ & $0.8-5.4$ \\
\hline total chlorophyll content $\left[\mathrm{mg} . \mathrm{l}^{-1}\right]$ & $9.1^{\mathrm{a}}$ & $4.8-13.1$ & $10.7^{\mathrm{a}}$ & $7.3-17.5$ & $9.7^{\mathrm{a}}$ & $6.1-13.5$ & $7.9^{\mathrm{a}}$ & $3.9-11.2$ \\
\hline chlorophyll a [mg.1 ${ }^{-1}$ ] & $5.8^{\mathrm{a}}$ & $2.9-9.0$ & $7.0^{\mathrm{a}}$ & $4.5-12.0$ & $6.3^{\mathrm{a}}$ & $3.7-8.9$ & $5.1^{\mathrm{a}}$ & $2.5-7.5$ \\
\hline chlorophyll b [mg.1 $\left.{ }^{-1}\right]$ & $3.6^{\mathrm{a}}$ & $1.9-5.5$ & $3.7^{\mathrm{a}}$ & $2.8-5.5$ & $3.4^{\mathrm{a}}$ & $2.4-4.5$ & $2.8^{\mathrm{a}}$ & $1.5-3.7$ \\
\hline $\mathrm{chl} \mathrm{a/chl} \mathrm{b}$ & $1.6^{\mathrm{a}}$ & $1.1-1.9$ & $1.8^{\mathrm{a}}$ & $1.6-2.2$ & $1.8^{\mathrm{a}}$ & $1.6-2.1$ & $1.8^{\mathrm{a}}$ & $1.7-2.1$ \\
\hline carotenoids [mg.l $\left.{ }^{-1}\right]$ & $2.1^{\mathrm{a}}$ & $1.2-3.0$ & $2.9^{\mathrm{a}}$ & $1.7-4.8$ & $2.3^{\mathrm{a}}$ & $1.7-2.9$ & $1.9^{\mathrm{a}}$ & $1.2-2.4$ \\
\hline
\end{tabular}

Table 2. Average, minimal and maximal values of Sphagnum fallax traits in control (C), warming (W), warming and reduced precipitation (WRP) and reduced precipitation (RP) conditions. Mean values with different letters $(\mathrm{a}-\mathrm{c})$ within each of the traits are significantly different from each other $(\mathrm{p}<0.05)$.

some random sites away from the experimental site (but still on floating peatland area), where both species were observed to be of comparable length (data not shown). But the longer S. angustifolium in comparison to S. fallax in manipulated sites indicates the manipulation negatively influenced the growth of S. fallax. S. fallax is considered to be having better productivity under acidic growth condition ${ }^{38}$, but the $\mathrm{pH}$ observation of water from different sites does not show any differences (data not shown). S. angustifolium is the moss considered to be growing better at an open area, which was the case of our manipulated site ${ }^{45}$. Good growth of S. angustifolium in comparison to other lawn Sphagnum spp. has been observed by different authors ${ }^{46}$. In a study the multispecies comparison performed during two contrasting years, wet and dry, showed higher biomass increment for $S$. angustifolium in the wet year ${ }^{23}$. The reduced rainfall during vegetation season was enough for the normal growth of S. angustifolium, which is visible on similar lengths of the plant and also capitulum diameter. However, shorter plants and smaller capitulum of S. fallax in RP and WRP conditions showed that reduced precipitation was not enough for their normal growth. It may be explained by that, if the drought lasts too long the Sphagnum water content drops under-compensation point, which causes irreversible damage ${ }^{40}$. The compensation point of $S$. fallax seems to be higher than that of S. angustifolium; therefore, S. angustifolium can better use accessible water after a period of dryness.

We collected only the wet and green Sphagnum from each plot; therefore, we can consider, all measured plants of both species in all plots were alive and photosynthetically active. Generally, under stress conditions, the chlorophyll content is lower in comparison to healthy plants ${ }^{47}$, but as the peatlands environment is water-saturated, and the Sphagnum can uptake the water through capillary action, the plants are able to maintain their photosynthetic activity. Warming may even induce the activity of certain enzymes involved in chlorophyll production, especially at morning hours when sunlight is sufficient, this may impact the total chlorophyll content positively. Chl a is the main photosynthetic pigment that forms core antenna molecules, whereas chl b are accessory molecules that participate in light harvesting ${ }^{48}$. In S. angustifolium, the total chlorophyll concentration was observed to be higher, which indicates a better photosynthetic condition for S. angustifolium when compared with S. fallax. Generally, the chl a/b ratio in the healthy plant is around 3, but in our observation, we observed the ratio to be around 2, which indicates in general photosynthetic apparatus was not intact in this period, which was in agreement with the previous observation on S. lindbergi ${ }^{12}$. An improvement in $\mathrm{chl} \mathrm{a} / \mathrm{b}$ ratio at the manipulated condition for both plant species indicated a better status of photosynthetic apparatus in manipulated conditions during the measurement period. Carotenoids are other important molecules in photosynthesis which capture the blue-green light and transfer it to chlorophyll ${ }^{49}$. There was a slight change in carotenoid concentration when compared between different experimental sites, but no significant differences were observed between the species.

Our results provide information that how the changes in precipitation may impact the Sphagnum population in northern peatlands. Different climate model indicates a sharp shift in precipitation where climate change may lead to a long drier period in northern region ${ }^{50}$. S. fallax is one of the most common Sphagnum mosses in European peat bogs ${ }^{51}$. Despite the fact that $S$. fallax prefers drier and nutrient richer habitats in comparison to S. angustifolium ${ }^{52}$, its growth was observed to be more dependent on precipitation, which is indicated by shorter 


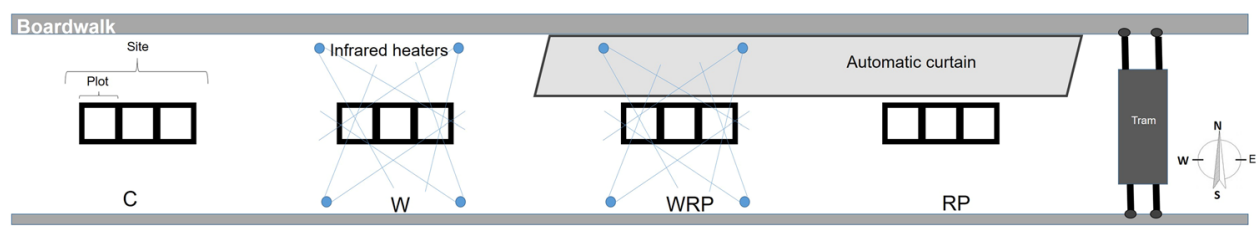

Figure 2. The illustrative diagram of the WETMAN climate manipulation experimental sites, showing four experimental conditions: control (C), warming (W), warming and reduced precipitation (WRP), and reduced precipitation (RP). The illustration also shows the positioning of infrared heaters and an automatic curtain. A rope driven tram is shown, which was used for passing over the plots for the purpose to collect samples.

plants of this species with smaller and lighter capitulum. These show the less adaptive capacity of $S$. fallax to studied manipulated conditions. The observation clearly indicated that among the two studied species S. angustifolium has better potential to survive in the climatic conditions where dry periods will be longer. Our results suggested that due to increased temperature and reduced availably of water, S. fallax can be substituted by another closely related species like $S$. angustifolium in conditions like northern Poland. The substitution can be due to better growth of S. angustifolium, which may outcompete the S. fallax. The shift in Sphagnum community composition is usually connected with the substitution of hollow species by hummock species ${ }^{20,36,38}$. Whereas, through this study, we have shown that the shift may also occur from one hollow species to another. Thus the study is important to understand how Sphagnum community may maintain ecosystem functioning when subject to future climatic condition. The shift in Sphagnum spp. is required to maintain the total peatland productivity and helps to maintain the carbon balance of peatland. The study is also important for peatland conservation as it helps to understand the behavior of two related Sphagnum spp.

\section{Material and Methods}

Study site. Plants for this study originated from experimental site WETMAN established in 2014 at Rzecin peatland $\left(52^{\circ} 45^{\prime} 43^{\prime \prime} \mathrm{N} 16^{\circ} 18^{\prime} 35^{\prime} \mathrm{E}, 54 \mathrm{~m}\right.$ a.s.l.) in Greater Poland region, north-western Poland ${ }^{53-55}$. Rzecin is a large complex of peatland ( $86 \mathrm{ha}$ ) with dominated mesotrophic fen. The fens are overgrown by vascular plants and mosses, and makes a floating peat-substrate carpet of $500-700 \mathrm{~mm}$ in the middle of the peatland. The experimental site is situated on the floating part of the peatland which was examined to be similar type of vegetation distribution in the year 2014. This fen has considerable biodiversity and possesses many rare plant species (e.g., Liparis loeselii, Carex dioica, Hamatocaulis vernicosus, Cinclidium stygium, Paludella squarrosa and Helodium blandowii). Dominant species of vegetation are Sphagnum spp. (in summary 11 taxa of Sphagnum), Carex rostrata (C. rostrata), C. lasiocarpa, C. limosa, Calamagrostis stricta, Phragmites australis, Typha latifolia, Oxycoccus palustris, Drosera rotundifolia, Ranunculus lingua, and Menyanthes trifoliata. According to FAO 2006 classification, the soil substrate is a Limnic Hemic Floatic Ombric Rheic Histosol (Epidystric) ${ }^{53,54}$.

WETMAN climate manipulation experiment consists of 4 experimental plots covering $2.5 \times 2.5 \mathrm{~m}$ of peatland (Fig. 2). The experimental sites are control (C), warming (W), reduced precipitation (RP), and combination of warming with reduced precipitation (WRP); within each of them, there are three experimental plots of size $0.7 \times 0.7 \mathrm{~m}$ as a main long-term experiment. The increase in temperature was achieved by installing four $400 \mathrm{~W}$ infrared radiators per W and WRP sites, while for reducing precipitation the automatic curtain covering at RP and WRP sites during the night was used. For the purpose to minimize the cost of heating the experimental plots are grouped together. In previous works the experimental setup and manipulation methods are described in detail $^{10,28,55}$

Temperature and precipitation measurements. Peat temperature was measured continuously in each of the twelve plots at $50 \mathrm{~mm}$ depth by using T-107 thermistors (Campbell Sci. USA). Precipitation was measured with the four-headed TPG-124-H24 rain gauges (ASTER, Poland) with two sensors exposed to rain-manipulated and two to non-rain-manipulated conditions.

Species identification and sampling. Live Sphagnum species were identified on-site using a microscope Zeiss Axioplan 2 (Carl Zeiss Microscopy, LLC, Thornwood, USA) and magnifiers with a magnification of x20 (Lichen candelaris $\mathrm{x} 20$ ). During identification, attention was paid to the most important features distinguishing two closely related Sphagnum species (Table 3). Sphagnum angustifolium (Warnst.) C.E.O. Jense has red branch-bases and a partially pure red stem, while Sphagnum fallax (Klinggr.) Klinggr. has a pale, green, or yellow stem and pale green or yellowish branches ${ }^{56}$. Moreover, S. angustifolium has shorter stem leaves than the type of S. fallax, and their apex is flattened and usually torned.

Samples were collected from the study site twice during summer 2018. The first sampling was performed on $20^{\text {th }} \mathrm{July}$, and the second was done on $18^{\text {th }}$ August 2018. For sampling each site is divided into three zones which correspond to the plots. The main drawback of WETMAN experimental sites is that plots are grouped together. By considering the size of the plants and selection process for WETMAN experiment where the peatland was carefully selected for plants with a similar mix of different plants and growth conditions, we can consider each plot to be separate. Plant samples were taken from the outside edge (maximum $15 \mathrm{~cm}$ from the metal frame, for the purpose to not disturb ongoing long-term measurement of carbon fluxes due to plant alteration) of the manipulated region. A rope operated tram (shown in Fig. 2) was used to go over the plot and collect the samples. Samples for chlorophyll measurement were taken from 5 plants per experimental plot (top $30 \mathrm{~mm}$ shoot was 


\begin{tabular}{|c|c|c|c|c|c|c|c|c|c|c|}
\hline \multirow[b]{2}{*}{ Species } & \multicolumn{3}{|l|}{ Colour } & \multicolumn{5}{|c|}{ Stem leaves } & \multirow{2}{*}{$\begin{array}{l}\text { Capitulum } \\
\begin{array}{l}\text { Capitulum } \\
\text { hemispherical }\end{array}\end{array}$} & \multirow{2}{*}{\begin{tabular}{|l|}
$\begin{array}{l}\text { Branch } \\
\text { leaves }\end{array}$ \\
$\begin{array}{l}\text { In 5-ranked } \\
\text { rows }\end{array}$ \\
\end{tabular}} \\
\hline & Green & \begin{tabular}{|l|} 
Partially \\
pure red \\
stem
\end{tabular} & \begin{tabular}{|l} 
Red \\
branch- \\
bases
\end{tabular} & $\begin{array}{l}\text { Small } \\
<1 \mathrm{~mm}\end{array}$ & \begin{tabular}{|l|} 
Ovate \\
triangular and \\
broadest at base
\end{tabular} & $\begin{array}{l}\text { Broadly } \\
\text { equilateral } \\
\text { triangular }\end{array}$ & $\begin{array}{l}\text { Apex } \\
\text { apiculate to } \\
\text { acute }\end{array}$ & $\begin{array}{l}\text { Obtuse } \\
\text { apex }\end{array}$ & & \\
\hline Sphagnum angustifolium & + & + & + & + & - & + & - & + & + & - \\
\hline Sphagnum fallax & + & - & - & $(+)$ & + & - & + & - & - & + \\
\hline
\end{tabular}

Table 3. Identification of species - most important macroscopic features. (Key diagnostic features which distinguish of Sphagnum angustifolium and S. fallax. Symbol + means valid for species, $(+)$ partially valid and - invalid.

taken for each) and were immediately stored in liquid nitrogen. For every sampling site (C, W, WRP and RP), at least three repeating samples consisted of 5 plants for each species were taken (in total, 15 plants of the same species were collected per site).

Plants for morphological measurements were separately packed in polybags and stored at $4{ }^{\circ} \mathrm{C}$ till measurements were performed at the laboratory.

Morphological measurements. Dry mass of whole plant, dry mass of capitulum, length of whole plant, length of the green and brown part of plant, capitulum diameter, length of the first three internodien and length of the longest one spreading and hanging branch from each of the first three nodien were measured for at least 11 plants from each site. The length of the whole plant was measured as a distance between the top of the capitulum and the end of the stem connected with capitulum. Part of the plant from capitulum (capitulum including) to visibly green-brown color transition was considered as the green part of a plant. Part of the plant from green-brown transition point to lower end was considered as the brown part. Length of the whole plant, its green and brown parts were measured by caliper (Topex. Warsaw. Poland) with $1 \mathrm{~mm}$ accuracy and length of internodien, spreading and hanging branches and capitulum diameter were measured with $0.1 \mathrm{~mm}$ accuracy.

Samples for dry mass were dried in the oven at $64^{\circ} \mathrm{C}$ until a constant weight was achieved. The dry mass of the whole plant and dry mass of capitulum were measured with $0.0001 \mathrm{~g}$ accuracy.

Plant pigment measurements. Samples were crushed in liquid nitrogen in a mortar till smooth and dry powder was obtained after the evaporation of nitrogen. Immediately after, $5 \mathrm{ml}$ of $80 \%$ acetone was added to the sample. The mixture was transferred to a test tube and centrifuged at 3000 RPM for 3 minutes by using centrifuge MPW-212 (MPW MED. INSTRUMENTS, Warsaw, Poland). The supernatant was immediately transferred to cuvette and absorbances at wavelengths $470 \mathrm{~nm}, 647 \mathrm{~nm}$ and $663 \mathrm{~nm}$ were measured by spectrophotometer SP-830 plus (Metertech Inc., Taipei. Taiwan). Chlorophyll and carotenoids contents were established according to the methodology established by Lichtenthaler ${ }^{57}$.

Statistical analysis. The differences between sites (C, W, WRP, and RP) for every trait and every species separately were analyzed using general linear mixed-effect models (GLMM), with each site (C, W, WRP and RP) as a random factor ${ }^{58}$. One-way ANOVA with Turkey HSD test was performed to analyze significant $(\mathrm{p}<0.05)$ differences for every trait and every species separately. All statistical analyses were carried out by using Statistica, ver. 12 (Statsoft Inc., Tulsa, OK, USA) and RStudio, ver. 2016 (RStudio Inc., Boston, MA, USA) ${ }^{59}$.

Received: 11 June 2019; Accepted: 15 April 2020;

Published online: 25 May 2020

\section{References}

1. IPCC, Global warming of $1.5^{\circ} \mathrm{C}$ - An IPCC Special Report on the impacts of global warming of $1.5^{\circ} \mathrm{C}$ above pre-industrial levels and related global greenhouse gas emission pathways, in the context of strengthening the global response to the threat of climate change, sustainable development, and efforts to eradicate poverty. IPCC Switzerland, (2018).

2. Radu, D. D. \& Duval, T. P. Precipitation frequency alters peatland ecosystem structure and $\mathrm{CO} 2$ exchange: Contrasting effects on moss, sedge, and shrub communities. Glob. Change Biol. 24, 2051-2065, https://doi.org/10.1111/gcb.14057 (2018).

3. Corlett, R. T. \& Westcott, D. A. Will plant movements keep up with climate change? Trends Ecol. Evol. 28, 482-488, https://doi. org/10.1016/j.tree.2013.04.003 (2013).

4. Elmqvist, T. et al. Response diversity, ecosystem change, and resilience. Front. Ecol. Environ. 1, 488, https://doi.org/10.1890/15409295(2003)001[0488:RDECAR]2.0.CO;2 (2003).

5. Gorham, E. Northern Peatlands: Role in the Carbon Cycle and Probable Responses to Climatic Warming. Ecol. Appl. 1, 182-195, https://doi.org/10.2307/1941811 (1991).

6. Bain, C. G., IUCN UK Commission of Inquiry on Peatlands. (IUCN UK Peatland Programme, 2011).

7. Yu, Z., Loisel, J., Brosseau, D. P., Beilman, D. W. \& Hunt, S. J. Global peatland dynamics since the Last Glacial Maximum. Geophys. Res. Lett. 37, 13, https://doi.org/10.1029/2010GL043584 (2010).

8. Gallego-Sala, A. Latitudinal limits to the predicted increase of the peatland carbon sink with warming. Nat. Clim. Change 8 , 907-913, https://doi.org/10.1038/s41558-018-0271-1 (2018).

9. Jassey, V. E. J. et al. Tipping point effect in plant-fungal interactions under severe drought causes abrupt rise in peatland ecosystem respiration. Glob. Change Biol. 24, 972-986, https://doi.org/10.1111/gcb.13928 (2018).

10. Rastogi, A. et al. Impact of Warming and Reduced Precipitation on Photosynthetic and Remote Sensing Properties of Peatland Vegetation. Env. Exp. Bot. 160, 71-80, https://doi.org/10.1016/j.envexpbot.2019.01.005 (2019).

11. Dorrepaal, E., Aerts, R., Cornelissen, J. H. C., Callaghan, T. V. \& van Logtestijn, R. S. P. Summer warming and increased winter snow cover affect Sphagnum fuscum growth, structure and production in a sub-arctic bog. Glob. Change Biol. 10, 93-104, https://doi. org/10.1111/j.1365-2486.2003.00718.x (2003). 
12. Hyyryläinen, A., Turunenb, M., Rautioc, P. \& Huttunen, S. Sphagnum mosses in a changing UV-B environment: A review. Perspect. Plant. Ecol. 33, 1-8, https://doi.org/10.1016/j.ppees.2018.04.001 (2018).

13. van Breemen, N. How Sphagnum bogs down other plants. Trends Ecol. Evol. 10, 270-275, https://doi.org/10.1016/01695347(95)90007-1 (1995).

14. Rydin, H., \& Jeglum, J. The Biology of Peatlands, second edition (Oxford University Press, 2013).

15. Slack N.G. The Ecological Value of Bryophytes as Indicators of Climate Change in Bryophyte Ecology and Climate Change (ed. Z., Tuba \& N.G., Slack) 3-12 (Cambridge University Press, 2011).

16. Hájek, T. \& Becket, R. P. Effect of Water Content Components on Desiccation and Recovery in Sphagnum Mosses. Ann. Bot. 101, 165-173, https://doi.org/10.1093/aob/mcm287 (2008).

17. Hayward, P. M. \& Clymo, R. S. Profiles of water content and pore size in Sphagnum and peat, ant treir relation to peat bog ecology. Proc. Royal Soc. B 215, https://doi.org/10.1098/rspb.1982.0044 299-325.

18. Tuba, Z. Notes on the poikilochlorophyllous desiccation-tolerant plants. Acta Biol. Szeged. 52, 111-113 (2008).

19. Weston, D. J. et al. Sphagnum physiology in the context of changing climate: emergent influences of genomics, modeling and host-microbiome interactions on understanding ecosystem function. Plant. Cell Environ. 38, 1737-1751, https://doi.org/10.1111/ pce.12458 (2015).

20. Norby, R. J., Childs, J., Hanson, P. J. \& Warren, J. M. Rapid loss of an ecosystem engineer: Sphagnum decline in an experimentally warmed bog. Ecol. Evol. https://doi.org/10.1002/ece3.5722 (2019).

21. Jassey, V. E. J. \& Signarbieux, C. Effects of climate warming on Sphagnum photosynthesis in peatlands depend on peat moisture and species-specific anatomical traits. Glob. Change Biol., https://doi.org/10.1111/gcb.14788 (2019).

22. Smith, A. J. E. The Moss Flora of Britain and Ireland, second edition (Cambridge University Press, 2004). https://doi.org/10.1017/ CBO9780511541858

23. Bengtsson, F., Granath, G. \& Rydin, H. Photosynthesis, growth, and decay traits in Sphagnum - a multispecies comparison. Ecol. Evol. 6, 3325-3341, https://doi.org/10.1002/ece3.2119(2016).

24. Turetsky, M. R. et al. The resilience and functional role of moss in boreal and arctic ecosystems. N. Physiol. 196, 49-67, https://doi. org/10.1111/j.1469-8137.2012.04254.x (2012).

25. Marschall, M. \& Borbély, P. Photosynthetic responses of the desiccation intolerant Sphagnum angustifolium in relation to increasing its desiccation tolerance by exogenous ABA. Acta Biol. Szeged. 55, 119-121 (2011).

26. Szurdoki, E., Márton, O. \& Szövényi, P. Genetic and morphological diversity of Sphagnum angustifolium, S. flexuosum and S. fallax in Europe. Taxon. 63, 237-248, https://doi.org/10.12705/632.6 (2014).

27. Buttler, A., Grosvernier, P. \& Matthey, Y. Development of Sphagnum fallax diaspores on bare peat with implications for the restoration of cut-over bogs. J. Appl. Ecol. 35, 800-810, https://doi.org/10.1046/j.1365-2664.1998.355351.x (1998).

28. Basińska, A. M. et al. Biomass changes in an active warming and precipitation reduction experiment on a Sphagnum peatland - the search for ecological indicators of climate change. Ecol. Indic. 112, 106059, https://doi.org/10.1016/j.ecolind.2019.106059 (2020).

29. Juszczak, R. et al. Towards better understanding of the response of Sphagnum peatland to increased temperature and reduced precipitation in Central Europe. Geophysical Research Abstracts 19, EGU2017-18838-1 (2017).

30. Łuców, D. et al. The response of vegetation structure to active warming and precipitation reduction of the Sphagnum peatland. Geophysical Research Abstracts 19, EGU2017-8001 (2017).

31. Rastogi, A. et al. The Impact of Climate Manipulation on Photosynthetic and Spectral Properties of Peatland Vegetation. Geophysical Research Abstracts 20, EGU2018-13685-1 (2018)

32. Vitt, D. H. \& Slack, N. G. Niche diversification of Sphagnum relative to environmental factors in northern Minnesota peatlands. J. Bot. 62, 1409-1430, https://doi.org/10.1139/b84-192 (1984).

33. Robroek, B. J. M., Limpens, J., Breeuwer, A. \& Schouten, M. G. C. Effects of water level and temperature on performance of four Sphagnum mosses. Plant. Ecol. 190, 97-107, https://doi.org/10.1007/s11258-006-9193-5 (2007).

34. Angela Breeuwer, Monique M. P. D. Heijmans, Bjorn J. M. Robroek, Frank Berendse, The effect of temperature on growth and competition between Sphagnum species. Oecologia 156(1), 155-167 (2008).

35. Asada, T., Warner, B. G. \& Banner, A. Growth of Mosses in Relation to Climate Factors in a Hypermaritime Coastal Peatland in British Columbia, Canada. Bryologist 106, 516-527 (2003).

36. Robroek, B. J. M., Schouten, M. G. S., Limpens, J., Berendse, F. \& Poorter, H. Interactive effects of water table and precipitation on net CO2 assimilation of three co-occurring Sphagnum mosses differing in distribution above the water table. Glob. Change Biol. 15, 680-691, https://doi.org/10.1111/j.1365-2486.2008.01724.x (2009).

37. Rydin, H., Gunnarsson, U., \& Sundberg, S. The Role of Sphagnum in Peatland Development and Persistence. in Boreal Peatland Ecosystems (ed. R. K., Wieder, D. H., Vitt) s. 47-65 (Springer-Verlag, Heidelberg, 2006).

38. Gunnarsson, U. Global patterns of Sphagnum productivity. J.Bryol. 27, 269-279, https://doi.org/10.1179/174328205X70029 (2005).

39. McCarter, C. P. R. \& Price, J. S. Ecohydrology of Sphagnum moss hummocks: mechanisms of capitula water supply and simulated effects of evaporation. Ecohydrology 7, 33-44, https://doi.org/10.1002/eco.1313 (2012).

40. Schipperges, B. \& Rydin, H. Response of Photosynthesis of Sphagnum Species from Contrasting Microhabitats to Tissue Water Content and Repeated Desiccation. N. Phytol. 140, 677-684, https://doi.org/10.1046/j.1469-8137.1998.00311.x (1998).

41. Zhaojun, B. et al. The response of peatlands to climate warming: A review. Acta Ecol. Sin. 31, 157-162, https://doi.org/10.1016/j. chnaes.2011.03.006 (2011).

42. Jassey, V. E. J. et al. Above- and belowground linkages in Sphagnum peatland: climate warming affects plant-microbial interactions. Glob. Change Biol. 19, 811-823, https://doi.org/10.1111/gcb.12075 (2012).

43. Jassey, V. E. J. et al. Tipping point effect in plant-fungal interactions under severe drought causes abrupt rise in peatland ecosystem respiration. Glob. Change Biol. 24, 972-986, https://doi.org/10.1111/gcb.13928 (2018).

44. Bragazza, L. et al. Persistent high temperature and low precipitation reduce peat carbon accumulation. Glob. Change Biol. 22, 4114-4123, https://doi.org/10.1111/gcb.13319 (2016).

45. Harley, P. Irradiance and temperature effects on photosynthesis of tussock tundra Sphagnum mosses from the foothills of the Philip Smith Mountains, Alaska. Oecologia 79, 251-259, https://doi.org/10.1007/BF00388485 (1989).

46. Lindholm, T. \& Vasander, H. Production of eight species of Sphagnum at Suurisuo Mire, southern Finland. Ann. Bot. Fenn. 27, $145-157$ (1990).

47. Ashraf, M. \& Harris, P. J. C. Photosynthesis under stressful environments: an overview. Photosynthetica 51, 163-190, https://doi. org/10.1007/s11099-013-0021-6 (2013).

48. Kalaji, H. M., Goltsev, V.N., Żuk-Gołaszewska, K., Zivcak, M., \& Brestic, M. Chlorophyll Fluorescence Understanding Crop Performance in Basics and Applications (CRC Press, 2017).

49. Hashimoto, H., Uragami, C. \& Cogdell, R. J. Carotenoids and photosynthesis. Subcell. Biochem. 79, 111-139, https://doi. org/10.1007/978-3-319-39126-7_4 (2016).

50. Trenberth, K. E. et al. Global warming and changes in drought. Nat. Clim. Change 4, 17-22, https://doi.org/10.1038/nclimate2067 (2014).

51. Robroek, B. J. M. et al. Taxonomic and functional turnover are decoupled in European peat bogs. Nat. Commun. 8, https://doi. org/10.1038/s41467-017-01350-5 (2017).

52. Maciej Gąbka, Mariusz Lamentowicz. Vegetation-Environment Relationships in Peatlands Dominated by Sphagnum fallax in Western Poland. Folia Geobotanica 43(4), 413-429 (2008). 
53. Acosta, M. et al. $\mathrm{CO}_{2}$ Fluxes from Different Vegetation Communities on a Peatland Ecosystem. Wetlands 37, 423-435, https://doi. org/10.1007/s13157-017-0878-4 (2017).

54. Juszczak, R., Acosta, M. \& Olejnik, J. Comparison of Daytime and Nighttime Ecosystem Respiration Measured by the Closed Chamber Technique on a Temperate Mire in Poland. Pol. J. Environ. Stud. 21, 643-658 (2012).

55. Rastogi, A., Bandopadhyay, S., Stróżecki, M. \& Juszczak, R. Monitoring the Impact of Environmental Manipulation on Peatland Surface by Simple Remote Sensing Indices. ITM Web Conf. 23, 30 (2018).

56. Nyholm, E. Illustrated moss flora of Fennoscandia II. Musci. Fasc. 6, (Natural Science Research Council, 1969).

57. Lichtenthaler, H. K. Chlorophylls and Carotenoids: Pigments of Photosynthetic Biomembranes. Plant. Cell Membr. 148, 350-382 (1987).

58. Pinheiro, J. C. \& Bates, D.M. Mixed-Effects Models in S and S-Plus. Springer. ISBN 0-387-98957-0. https://link.springer.com/ book/10.1007/b98882 (2000)

59. RStudio Team (2016). RStudio: Integrated Development for R. RStudio, Inc., Boston, MA, http://www.rstudio.com/.

\section{Acknowledgements}

The research was co-founded by the National Science Centre of Poland within the OPUS project (No. 2016/21/B/ ST10/02271): "Sun induced fluorescence and photosynthesis of peatland vegetation response to stress caused by water deficits and increased temperature under conditions of climate manipulation experiment" (2017-2020) and the Polish National Centre for Research and Development within the Polish-Norwegian Research Programme within the WETMAN project (Pol-Nor/203258/31/2013): Central European Wetland Ecosystem Feedbacks to Changing Climate - Field Scale Manipulation (2013-2016). Most importantly authors would like to thank all the WETMAN team members who worked on the station and helped to develop and maintain the WETMAN climate manipulation infrastructure in the period 2013-2016, especially to Janusz Olejnik, Jacek Leśny, Marek Urbaniak, Bogdan Chojnicki, Damian Józefczyk, Mateusz Samson, Mariusz Lamentowicz, Dominika Łuców, Anna Basińska, Monika Reczuga, and Hanna Silvennoinen.

\section{Author contributions}

A.R. and M.G. conceptualized the project. M.A., A.R., R.J. and M.G. collected the data and analyzed the results. S.R. identified the species on the field and laboratory. M.S. collected rain and temperature data. R.J. provided funding and infrastructure. A.R. and M.G. supervised the work. M.B. co-supervised the ERASMUS student work and helped in analysis. M.A. and A.R. prepared the original draft of the manuscript. A.R., R.J., M.G., M.B. and M.S. read and edited the manuscript.

\section{Competing interests}

The authors declare no competing interests.

\section{Additional information}

Supplementary information is available for this paper at https://doi.org/10.1038/s41598-020-65032-x.

Correspondence and requests for materials should be addressed to A.R. or M.G.

Reprints and permissions information is available at www.nature.com/reprints.

Publisher's note Springer Nature remains neutral with regard to jurisdictional claims in published maps and institutional affiliations.

(c) (i) Open Access This article is licensed under a Creative Commons Attribution 4.0 International License, which permits use, sharing, adaptation, distribution and reproduction in any medium or format, as long as you give appropriate credit to the original author(s) and the source, provide a link to the Creative Commons license, and indicate if changes were made. The images or other third party material in this article are included in the article's Creative Commons license, unless indicated otherwise in a credit line to the material. If material is not included in the article's Creative Commons license and your intended use is not permitted by statutory regulation or exceeds the permitted use, you will need to obtain permission directly from the copyright holder. To view a copy of this license, visit http://creativecommons.org/licenses/by/4.0/.

(C) The Author(s) 2020 